\title{
Nitrogen and the future of agriculture: 20 years on
}

\author{
This article belongs to Ambio's 50th Anniversary Collection. Theme: Solutions-oriented \\ research
}

\author{
Kenneth G. Cassman, Achim Dobermann
}

Published online: 14 March 2021

\section{GLOBAL VIEW}

Adequate crop yields to feed 7.8 billion people today, and nearly 10 billion by mid-century (Vollset et al. 2020), depend on large amounts of nitrogen $(\mathrm{N})$ input, which in turn represent an inherent weakness in our global food production system. The challenge has nothing to do with $\mathrm{N}$ supply as that is virtually unlimited. Nearly $80 \%$ of the atmosphere is composed of $\mathrm{N}_{2}$, a relatively inert gas, that can be converted to reactive $\mathrm{N}$ forms (mostly nitrate, $\mathrm{NO}_{3}{ }^{-}$ and ammonium, $\mathrm{NH}_{4}{ }^{+}$) via biological and industrial processes and used to satisfy crop $\mathrm{N}$ requirements. Instead, the main problem is one of excess: it is difficult to precisely supply enough $\mathrm{N}$ to meet crop physiological requirements while also controlling the fate of reactive $\mathrm{N}$ to avoid losses to the environment. As a result, cropping systems responsible for the bulk of humanity's food supply leak too much $\mathrm{NO}_{3}{ }^{-}$, causing severe degradation of water quality and riparian and aquatic ecosystems. Gaseous losses as ammonia, nitrogen oxides $\left(\mathrm{NO}_{x}\right)$, and nitrous oxide $\left(\mathrm{N}_{2} \mathrm{O}\right)$ reduce air quality and account for much of agriculture's contribution to climate change. To make up for these losses, the global annual input of fertilizer $\mathrm{N}$ to cropland is double the $\mathrm{N}$ input from the natural processes of biological $\mathrm{N}$ fixation (BNF) (Fowler et al. 2013). At the same time, crops in large parts of the world, and particularly in subSaharan Africa (SSA), suffer chronic N deficiency and low yields due to lack of sufficient input of $\mathrm{N}$ and other nutrients (Berge et al. 2019; Senthilkumar et al. 2020).

These concerns were well documented and recognized within the scientific community when our 2002 Ambio paper (Cassman et al. 2002) was presented at the $2 n d$ International Nitrogen Conference in Washington DC (October 2001). Achieving better synchrony between $\mathrm{N}$ supply and demand across the wide range of cropping systems and environments in which crops are grown was identified as the solution to both meet crop $\mathrm{N}$ needs and better protect environmental quality. But it was difficult to find robust and relevant field data on $\mathrm{N}$ fertilizer efficiency (NFE, also called recovery efficiency of fertilizer N) of major food crops as quantified by the proportion of applied $\mathrm{N}$ taken up the crop. Such data are essential for monitoring and mapping $\mathrm{N}$ losses to identify crops and regions with greatest potential for improvement, or areas where progress has been made.

To that end, our paper brought together the best available data on NFE for the major grain crops rice, wheat, and maize to establish benchmarks based on direct measurements taken as much as possible in farmer-managed production fields. Although there is a copious literature on NFE measured in "small-plot" experiments, estimates from those studies are not representative of NFE in larger, non-uniform production fields as managed by farmers. Our results documented relatively low NFE of $18-49 \%$ occurring at production scale in several major cereal systems depending on crop species, cropping system, and country. While not good news for the environment because such low levels of NFE equate to more than $50 \mathrm{Tg}$ of applied fertilizer $\mathrm{N}$ not taken up by crops ${ }^{1}$ and at risk of loss, it documents enormous room for improvement.

In recent years, approaches to estimate $\mathrm{N}$ use efficiency ${ }^{2}$ have focused on constructing $\mathrm{N}$ budgets and $\mathrm{N}$ use efficiency indicators based on estimates of $\mathrm{N}$ inputs and

\footnotetext{
${ }^{1}$ Current annual global fertilizer $\mathrm{N}$ use on cropland is about $100 \mathrm{Tg}$ (excluding grasslands and forage crops).

${ }^{2} \mathrm{~N}$ use efficiency is a broader measure than NFE because, in addition to applied $\mathrm{N}$ fertilizer, it also includes $\mathrm{N}$ supply from mineralization of soil organic matter, and $\mathrm{N}$ inputs from manure, BNF and atmospheric deposition, all of which contribute to the $\mathrm{N}$ supply for crop uptake.
} 
outputs at farm (Quemada et al. 2020), national (Zhang et al. 2015), and global scales (Ladha et al. 2016). General conclusions from this work are consistent with our 2002 Ambio paper: $\mathrm{N}$ use efficiency varies widely but is often well below achievable levels. Using input-output budgeting approaches, global $\mathrm{N}$ use efficiency from crop production is currently in the $40-50 \%$ range. $^{3}$ Few studies since 2002 have added new data on NFE from farmermanaged production fields, or on critical nutrient budget components such as $\mathrm{N}$ inputs from biological fixation and the amount of $\mathrm{N}$ released from mineralization of soil organic matter (SOM). Hence, large uncertainties remain with data and coefficients used to construct such nutrient budgets (Zhang et al. 2020).

At a global scale, average $\mathrm{N}$ use efficiency has increased slowly during the past 20 years. A general proxy for NFE trajectories can be seen in time-trends for $\mathrm{N}$ fertilizer use versus the amount of $\mathrm{N}$ removed with harvested crop materials. In high-yield cropping systems of North America, for example, $\mathrm{N}$ removal was considerably less than applied N fertilizer from 1960 to 1970 (an indication of N excess), and considerably more than applied in recent decades (Fig. 1a). This crossover reflects improved NFE due to rising crop yields, modest improvements in $\mathrm{N}$ fertilizer management, and increased soybean production, the latter a legume crop with large capacity to meet its $\mathrm{N}$ demand through BNF, thus requiring little $\mathrm{N}$ fertilizer (Salvagiotti et al. 2008). Greater $\mathrm{N}$ removal than $\mathrm{N}$ fertilizer inputs in Latin America also reflects both increasing crop yields and large expansion of soybean-based cropping systems in Argentina, Brazil, Paraguay, and Uruguay (Fig. 1g).

A narrowing gap between $\mathrm{N}$ fertilizer inputs and $\mathrm{N}$ removal also indicates a trend towards improved NFE as seen in the high-yield systems of Western and Central Europe (Fig. 1b) and more recently in East Asia, which mostly reflects trends in China (Fig. 1f). Improved NFE in these regions largely results from more judicious use of $\mathrm{N}$ fertilizer in response to policies and regulations promoting higher NFE rather than the benefits of increasing crop yields. In Eastern Europe and Central Asia, the decline in N fertilizer use that resulted from collapse of the former U.S.S.R. has been reversed along with rising crop yields, with indications of a trend towards higher NFE (Fig. 1c). Offsetting these positive trends is the widening gap between $\mathrm{N}$ fertilizer inputs and $\mathrm{N}$ removal in cropping systems of West and South Asia, which suggest decreasing NFE (Fig. 1d,1e).

\footnotetext{
${ }_{3}$ Most published estimates are for time series until 2010, with global cropland $\mathrm{N}$ use efficiency estimates ranging from about 42 to $47 \%$, e.g., Lassaletta et al. (2014); Zhang et al. (2015).
}

After years of stagnation, fertilizer use in sub-Saharan Africa has started to increase, from about $8 \mathrm{~kg}$ nutrients $\mathrm{ha}^{-1}$ in 2000 to about $20 \mathrm{~kg} \mathrm{ha}^{-1}$ today, ${ }^{4}$ although the gap between crop $\mathrm{N}$ removal and fertilizer $\mathrm{N}$ use has widened in recent years (Fig. 1h). As a result, current farm yields are less than $33 \%$ of attainable yield with currently available technologies (van Ittersum et al. 2016) and soil nutrient stocks are being depleted. Closing the African yield gap will require reducing the gap between physiological nutrient requirements and the amount of applied nutrients on a massive scale (Berge et al. 2019).

Increased public concern about $\mathrm{N}$ pollution in many high- and middle-income countries has led to regulatory action and a range of policies related to $\mathrm{N}$ pollution (Kanter et al. 2020). Limits on the amount of $\mathrm{N}$ fertilizer have been implemented in some countries, while other jurisdictions rely on voluntary measures or use a relatively straightforward "N balance" approach (the difference between $\mathrm{N}$ inputs and $\mathrm{N}$ removal in harvested materials) as the means to track progress towards environmental goals (McLellan et al. 2018). A key challenge in all such programs is the capacity to link NFE at the level of a farmer's field or farm to environmental outcomes at the watershed or groundwater resource scale because of large deficiencies in ability to accurately model crop $\mathrm{N}$ uptake, $\mathrm{N}$ cycling through soil organic matter, and losses of reactive $\mathrm{N}$ via leaching and gaseous emissions. While farmers can easily monitor $\mathrm{N}$ balance, it is much more difficult to estimate NFE because it is confounded by uptake of indigenous soil $\mathrm{N}$ from mineralization of SOM and residual $\mathrm{N}$ from applications to the previous crop. Although ability to predict $\mathrm{N}$ supply from soil $\mathrm{N}$ mineralization across a wide range of soil types and climates remains a difficult scientific challenge, it would give farmers a powerful tool to improve synchronization of crop demand and $\mathrm{N}$ supply throughout the growing season through improved timing and amount of $\mathrm{N}$ topdressings. Despite widespread concerns about N pollution from agriculture and regulations to reduce it, we believe that public- and private-sector investment explicitly focused on raising crop yields while also decreasing $\mathrm{N}$ losses is woefully inadequate relative to the magnitude of the challenge and associated societal benefits.

\section{NITROGEN INNOVATIONS}

In our 2002 paper, we proposed an "N synchrony framework" for evaluating promising technologies to achieve "just-in-time N supply," without excess or deficiency, throughout the crop growth cycle as the means to achieve

\footnotetext{
${ }^{4}$ Based on IFASTAT Fertilizer Consumption and Fertilizer Use By Crops databases, IFA, Paris.
} 

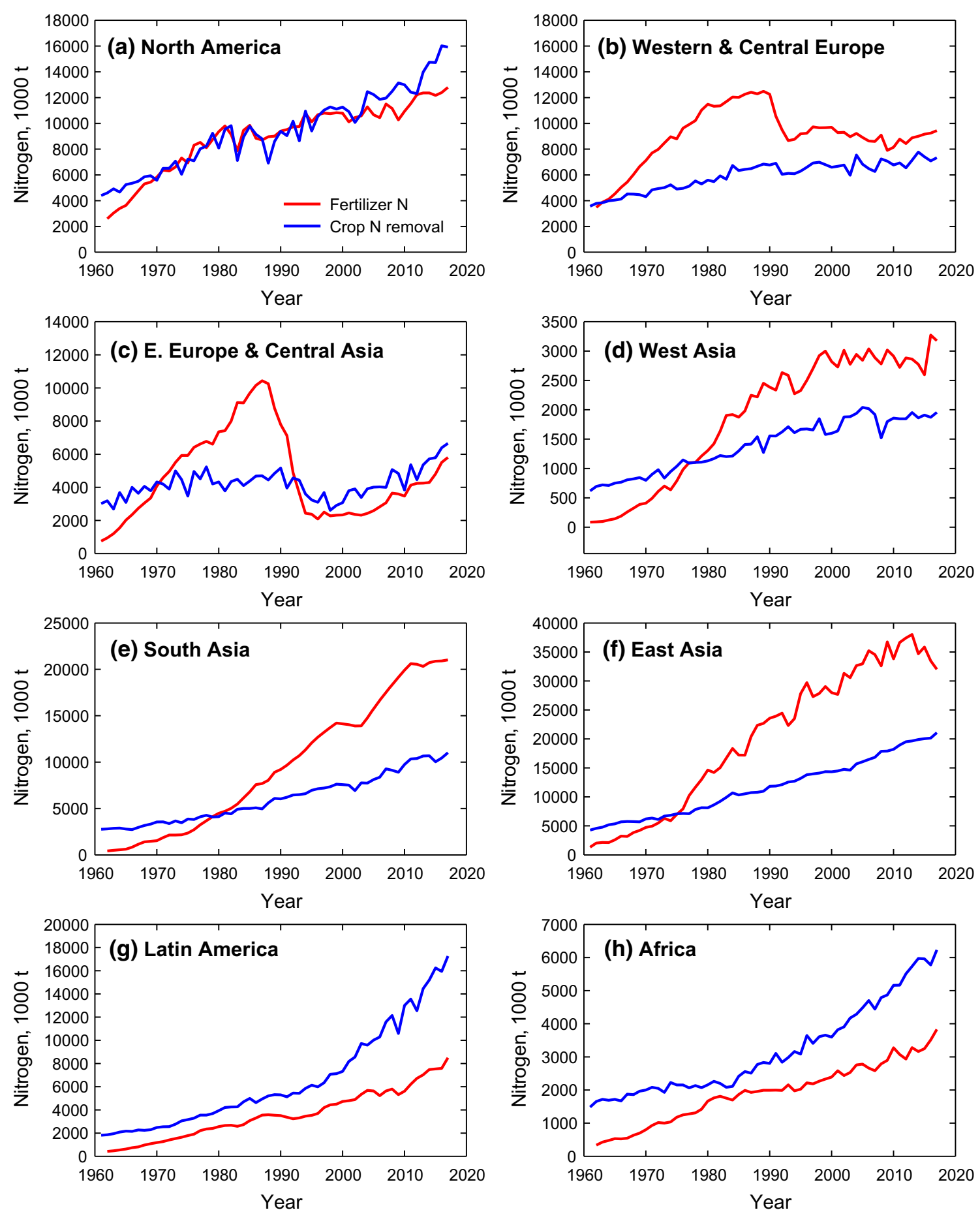

Fig. 1 Trends in fertilizer N use and crop N removal by region, 1961-2017. Data source IFA Nutrient Use Efficiency database, IFASTAT, 2020. The dataset contains national scale estimates for $\mathrm{N}$ inputs to cropland from fertilizer, manure and biological $\mathrm{N}$ fixation, as well as $\mathrm{N}$ removal by harvested crops. Grasslands and forage crops are not included

meaningful increases in NFE at scale. The need to concomitantly increase crop yields and NFE was the primary justification for this approach (Cassman 1999) because crops that absorb more of the available $\mathrm{N}$ and transform it into economic yield offer the best path to achieve both goals, thereby decreasing the amount of $\mathrm{N}$ at risk of loss to the environment. A number of promising technology options were identified. Here, we evaluate progress over the subsequent two decades. 
Trends in Fig. 1 suggest that in some regions, either motivated by voluntary incentive schemes or regulatory policies (van Grinsven et al. 2015), changes in management practices and/or adoption of new technologies have contributed to improved $\mathrm{N}$ efficiency. It is difficult, however, to attribute improvements to adoption of specific technologies because NFE improvement can occur from technologies other than fertilizer management. Hence, widespread adoption of practices that contribute to more uniform plant stands, higher plant densities, more vigorous early season growth rates, and higher yields have indirectly increased NFE when there is excess $\mathrm{N}$ supply. In mechanized systems, these practices include use of integrated pest management, GMO crops that reduce yield loses from weeds and insect pests, and precision-farming technologies such as auto-steer tractors guided by global positioning systems that avoid strips without $\mathrm{N}$ fertilization and $\mathrm{N}$ fertilizer overlaps. A general movement away from a single large $\mathrm{N}$ fertilizer application before planting or at sowing towards smaller, split applications during the growing season has been promoted to farmers in highyield cereal production systems worldwide, although it is difficult to obtain good data on the degree of adoption by farmers.

In contrast, compared to its theoretical promise (Cassman and Plant 1992), adoption of variable-rate fertilization technology has been disappointing. Lack of adoption by large-scale mechanized farmers appears to reflect an unproven value proposition for the required investments in equipment, software, data, and labor to implement variable-rate fertilizer application, while low levels of motorized mechanization represents the biggest adoption barrier for medium and small farms in developing countries (Lowenberg-DeBoer and Erickson 2019). To overcome these barriers for small farms, a considerable body of research has produced a number of "low-tech" site-specific nutrient management (SSNM) tools that give consistent increases in crop yields and profits (typically by 10-20\% relative to current farmers' practice) and $\mathrm{N}$ use efficiency (typically by $30-40 \%$ ) in many crops, including rice, wheat, maize, and other crops in Asia and Africa (Dobermann et al. 2002; Khurana et al. 2008; Chen et al. 2014; Pasuquin et al. 2014; Saito et al. 2015; Rurinda et al. 2020; Wang et al. 2020). These substantial improvements have been achieved across a wide range of environments and are typically associated with a modest reduction in $\mathrm{N}$ fertilizer rates and a shift towards more split $\mathrm{N}$ applications to improve congruence between $\mathrm{N}$ supply and crop $\mathrm{N}$ demand. It is likely that adoption of these tools also reduces $\mathrm{NO}_{3}$ leaching and $\mathrm{N}_{2} \mathrm{O}$ emission losses (Pampolino et al. 2007; An et al. 2015). We know of no other intervention that has demonstrated such robust, win-win performance across large regions.
Yet despite robust validation of the SSSM approach, it has been a challenge to achieve widespread adoption by millions of smallholder farmers, for which a combination of conventional and digital extension education tools have been tested (Pampolino et al. 2012; Cui et al. 2018; Sharma et al. 2019; Zossou et al. 2020). Experience thus far suggests multiple reasons for limited impact at larger scale, including: weak capacity in government extension systems, insufficient private-sector uptake, decision tools that are still too complex to use and do not have sustainable business models, lack of integration with financial and input supply services, insufficient integration of other agronomically relevant and geospatial information, and lack of policy-driven incentives to promote farmer adoption.

"Smart" fertilizer formulations and specialty products designed to regulate specific $\mathrm{N}$ transformation pathways in soil to better synchronize $\mathrm{N}$ supply and demand have been around for decades. Yet progress towards defining the conditions under which these products work has been slow, and inconsistency of expected returns from their use have limited widespread adoption. Enhanced-efficiency fertilizers $^{5}$ currently account for less than $5 \%$ of the global fertilizer $\mathrm{N}$ market. Nitrogen transformation inhibitors and other N fertilizer "stabilizers" applied to broadacre crops account for the bulk of that market, whereas controlledand slow-release fertilizers are mostly applied to highvalue crops such as turf, ornamentals, nurseries and plantations. Biological nitrification inhibition-the ability of plant roots to suppress soil-nitrifier activity through production and release of nitrification inhibitors-has been proposed as an innovative genetic modification pathway to reduce $\mathrm{N}_{2} \mathrm{O}$ emissions (Subbarao et al. 2017). Although scientifically interesting, we doubt it has potential for realworld impact due to the complexity of regulating expression of this trait in response to both $\mathrm{N}$ supply and crop $\mathrm{N}$ demand as they change throughout the crop growth cycle.

Crop genetic improvement is often emphasized for its promise to improve $\mathrm{N}$ use efficiency, as mentioned in our Ambio paper (Cassman et al. 2002). However, we are not aware of new crop varieties with proven improvement of specific traits governing $\mathrm{N}$ efficiency or BNF despite many millions of dollars of public- and private-sector investment towards these goals. Breeding for $\mathrm{N}$ use efficiency must coordinate genetic control of physiological and metabolic factors influencing $\mathrm{N}$ uptake from soil and $\mathrm{N}$ utilization efficiency and allocation within the plant. And both processes involve numerous finely tuned biochemical pathways and feedback mechanisms that are highly sensitive to environmental conditions (Cormier et al. 2016; van

\footnotetext{
5 This includes controlled-release fertilizers, slow-release fertilizers, sulfur-coated fertilizers, stabilized nitrogen fertilizers (urease inhibitors, nitrification inhibitors, etc.).
} 
Lammerts Bueren and Struik 2017), making "trade-off" free genetic solutions unlikely (Denison 2015).

For similar reasons, there has been little progress towards increased contributions from BNF by legume crops, or developing cereal crops with $\mathrm{N}$ fixation capability (Ladha and Reddy 1995; Beatty and Good 2011; Rogers and Oldroyd 2014). Impressive basic research has been conducted on different approaches, including improvement of root-associated endophytic bacteria to develop noduleindependent $\mathrm{N}_{2}$-fixing systems, engineering root nodule symbiosis in cereals, and transferring nitrogenase genes into cereal crops. Despite progress in expanding scientific knowledge, none of these approaches-if they work-are likely to reach commercialization within the next 20 or 30 years because of the number of genes involved. In recent years, commercial activity has focused on identification and/or improvement of endophytic bacteria for associative $\mathrm{N}$ fixation. Several companies aim to commercialize endophytic products in the near future, but more rigorous, independent field testing is still required. At best, such microbial formulations have potential to contribute relatively small amounts of about $20-30 \mathrm{~kg} \mathrm{~N}^{-1}$ during a cropping season, compared to typical $\mathrm{N}$ uptake requirements of about $200 \mathrm{~kg} \mathrm{~N} / \mathrm{ha}$ for high-yielding cereal crops, and similar large amounts from legume BNF inputs.

Two notable trends have emerged in the global $\mathrm{N}$ balance since we wrote our paper. First, industrial $\mathrm{N}$ is becoming a key ingredient in global sustainability chains, including uses to reduce emissions in transportation and power stations, construction, extraction and processing of mineral resources, feed additives, wastewater treatment, and pharmaceuticals. Industrial uses of inorganic $\mathrm{N}$ (mainly as ammonia, urea, and ammonium nitrate) now represent around $20 \%$ (ca. $33 \mathrm{Mt}$ ) of total industrial $\mathrm{N}$ production. Annual growth of that sector has averaged $4-5 \%$ during the past 20 years and is likely to continue or accelerate. Efficiencies and losses from these multiple enduses have not been well quantified, but this is also a rapidly emerging area to support development of new green technologies.

Second, there has been massive growth in livestock production and associated nutrient pollution as demand for meat and dairy products has soared with rapid economic and income growth, particularly in countries such as China and India. Nitrogen losses from livestock systems and virtual trade in $\mathrm{N}$ are now estimated at $65 \mathrm{Tg} \mathrm{N}_{\text {year }}{ }^{-1}$, or one-third of all human-induced $\mathrm{N}$ losses to the environment (Uwizeye et al. 2020). Continued growth in livestock production is anticipated as economic growth spreads to other populous, low-income countries in Asia, Latin America, and Sub-Sahara Africa where farm animals can play a pivotal role in creating a new, circular food system for meeting both dietary requirements and environmental protection (van Zanten et al. 2019). This megatrend calls for innovation in developing improved livestock production systems and business models that include opportunities for nutrient recovery and recycling. Several major companies and venture capital startups are investing in such technologies.

It is frequently suggested that food system solutions must include substantial shifts in diets to reduce consumption of livestock products and large reductions in food losses or waste (Foley et al. 2011; Springmann et al. 2018; Willett et al. 2019). In countries like China, such transformations could contribute significantly to future cropland, grassland and nutrient needs (Ma et al. 2019). While technically feasible, however, we see little scope for either option to substantially reduce $\mathrm{N}$ input requirements in crop production within a relevant time frame for impact. To our knowledge there is scarce evidence that diets can be substantially modified in developed countries with high meat and dairy consumption, or in low-income developing countries where current levels of meat and dairy consumption are so low that nutrition is greatly improved by increased consumption as economic development proceeds. We are also uncertain about the potential for alternative protein sources and production systems from industrial scale cell culture, insects, or plant-based meat mimics. If these technologies can displace meat production from livestock, they could achieve a large reduction in $\mathrm{N}$ use and losses from conventional agriculture. But it is not at all clear that diet change of any kind will achieve widespread consumer acceptance simply because dietary preferences are so tightly interwoven with culture and heritage.

\section{OUTLOOK}

We are left with the synchronization framework proposed 20 years ago, and an urgent call for innovation and open thinking to redesign agriculture in terms of crops, cropping systems, integrated crop-livestock systems with better nutrient recycling and recovery, and the agricultural landscape itself in terms of hydraulic flows and conservation features such as riparian buffers and constructed wetlands. Capture and recycling of $\mathrm{N}$ (and $\mathrm{P}$ ) from multiple waste streams will likely become increasingly important.

We remain highly skeptical of the potential for singlefactor genetic improvements in $\mathrm{N}$ use efficiency, or other "single-factor" genetic technologies to pay off. Instead, we see most promise in systematic agronomic approaches that harness Big Data and geospatial extrapolation frameworks to accelerate the process of optimizing crop and soil management practices governing both yields and resource use efficiencies at production scale (Cassman and Grassini 
2020). Traditional, replicated field studies with two or three treatment variables are not up to the task of optimizing the 10-20 management factors (including selection of the optimal hybrid or cultivar) that affect NFE, crop yield, profit, and other key performance indicators. Machine learning and other artificial intelligence approaches can play an important role in developing optimized, tailored, and site-specific management solutions (Saikai et al. 2020), particularly once it becomes possible to move seamlessly from data to prescriptive analytics and automated decision making (Smith 2020). The rapid spread of GPS-enabled smartphones presents a unique opportunity for directly reaching 2 billion people in smallholder farming households, provided the smartphone apps and messages are scientifically sound, give actionable advice, and utilize feedback mechanisms to enable rigorous testing and continuous improvement (Fabregas et al. 2019). Public access to high-quality, high spatial resolution data on soil properties, long-term weather records, current weather conditions, and robust weather forecasts represent essential and relatively low-cost "public goods" to support the needed innovation and should be given a high priority by policymakers.

We also note that while substantial improvement in NFE is necessary, it is not sufficient to meet water quality standards in major crop producing regions like the US Corn Belt. Cover crops, conservation tillage, and modified cropping systems may also be required (Castellano and David 2014), as well as retirement of the most sensitive land from crop production. For example, strategic conversion of $<3 \%$ of cropland in the Upper Mississippi, Ohio, and Missouri River watersheds is estimated to achieve a $45 \%$ reduction in nitrate losses and reduce extent of the hypoxia zone within regulatory targets (McLellan et al. 2015).

The current global food system relies on a handful of staple crops, ${ }^{6}$ many of which are grown in a few "breadbasket" regions with good soils and favorable climates, to produce consistently high yields in sufficient quantities to meet global demand for calories, protein, and vegetable oil. While many other crops contribute importantly to human food supply and nutrition at a national scale, none are widely traded on global markets to supply the majority of countries that rely on food imports for a substantial portion of total food requirements. Hence, our current food system depends on globalized production and trade in crop and livestock commodities, and modern science and technology to produce them. We see continuation of this globalized food system in a post-pandemic world because it fosters crop production where soils and climate give comparative

\footnotetext{
${ }^{6}$ The key crops include rice, wheat, maize, potatoes and sweet potatoes, cassava, soybean, oil palm, sugarcane, and sugarbeets.
}

advantages in capture of sunlight and conversion into human food with greatest efficiency in use of inputs such as labor, nutrients, water, and energy. While some nations may have comparative advantage for production of rice, others have advantages for maize, soybean, wheat, potatoes, or oil palm. Global trade, economic development, social and economic equality provide the means to support balanced diets in a world without hunger and without further environmental degradation. And while recent studies have estimated $\mathrm{N}$ balance limits within the planetary boundary concept (Steffen et al. 2015; Zhang et al. 2015), the range is too large to be an effective target at the field or farm level. Emphasis should be given to better estimating acceptable $\mathrm{N}$ loss limits at the field level so that farmers and supporting agricultural industries can innovate to reach them across the wide range of soils, climates, and crops that comprise our major food production systems. It is notable that the knowledge and tools to better estimate environmental performance limits at a field scale, as influenced by soil, weather, cropping system, and management practices, would also strongly contribute to developing technologies that improve NFE by achieving greater synchrony in $\mathrm{N}$ supply and demand.

Despite the enormity of the challenge, we are confident that environmental damage and human health problems caused by $\mathrm{N}$ losses from modern, high-yield agriculture can be eliminated within 30 years. But our confidence assumes that policy-makers have the vision to make adequate $R \& D$ investments with a ruthless focus on accelerating yield growth of major food crops on existing farmland while concomitantly increasing NFE, as well as transparent environmental performance standards, and robust, low-cost metrics that allow farmers to monitor progress towards those standards. Policies to meet this grand challenge include adequate public investment in education and human resource development, as well as free public access to high-quality data on soil properties, historical and realtime weather data, and water resources at a spatial resolution sufficient to drive innovation towards increasingly precise crop and soil management in farmers' fields to optimize productivity and avoid negative environmental consequences.

Acknowledgements The authors wish to recognize the contributions of Daniel T. Walters, who was a co-author and dear colleague on our original 2002 Ambio paper, but who passed away in 2010.

\section{REFERENCES}

An, N., M. Fan, F. Zhang, P. Christie, J. Yang, J. Huang, S. Guo, X. Shi, et al. 2015. Exploiting co-benefits of increased rice production and reduced greenhouse gas emission through optimized crop and soil management. PLoS ONE 10: e0140023. 
Beatty, P.H., and A.G. Good. 2011. Future prospects for cereals that fix nitrogen. Science 333: 416-417. https://doi.org/10.1126/ science. 1209467.

Cassman, K.G., and R.E. Plant. 1992. A model to predict crop response to applied fertilizer nutrients in heterogenous fields. Fertilizer Research 31: 151-163.

Cassman, K.G. 1999. Ecological intensification of cereal production systems: Yield potential, soil quality, and precision agriculture. Proceedings of the National Academy of Sciences 96: 5952-5959.

Cassman, K.G., A. Dobermann, and D.T. Walters. 2002. Agroecosystems, nitrogen-use efficiency, and nitrogen management. Ambio 31: 132-140. https://doi.org/10.1579/0044-7447-31.2. 132.

Cassman, K.G., and P. Grassini. 2020. A global perspective on sustainable intensification research. Nature Sustainability 3: 262-268. https://doi.org/10.1038/s41893-020-0507-8.

Castellano, M.J., and M.B. David. 2014. Long-term fate of nitrate fertilizer in agricultural soils is not necessarily related to nitrate leaching from agricultural soils. Proceedings of the National academy of Sciences of the United States of America 111: E766. https://doi.org/10.1073/pnas.1321350111.

Chen, X., Z. Cui, M. Fan, P. Vitousek, M. Zhao, W. Ma, Z. Wang, W. Zhang, et al. 2014. Producing more grain with lower environmental costs. Nature 514: 486-489. https://doi.org/10.1038/ nature 13609.

Cormier, F., J. Foulkes, B. Hirel, D. Gouache, Y. Moënne-Loccoz, and J. Le Gouis. 2016. Breeding for increased nitrogen-use efficiency: A review for wheat (T. aestivum L.). Plant Breeding 135: 255-278. https://doi.org/10.1111/pbr.12371.

Cui, Z., H. Zhang, X. Chen, C. Zhang, W. Ma, C. Huang, W. Zhang, G. Mi, et al. 2018. Pursuing sustainable productivity with millions of smallholder farmers. Nature 555: 363-366. https:// doi.org/10.1038/nature25785.

Denison, R.F. 2015. Evolutionary tradeoffs as opportunities to improve yield potential. Field Crops Research 182: 3-8.

Dobermann, A., C. Witt, D. Dawe, S. Abdulrachman, G.C. Gines, R. Nagarajan, S. Satawathananont, T.T. Son, et al. 2002. Sitespecific nutrient management for intensive rice cropping systems in Asia. Field Crops Research 74: 37-66.

Fabregas, R., M. Kremer, and F. Schilbach. 2019. Realizing the potential of digital development: The case of agricultural advice. Science. https://doi.org/10.1126/science.aay3038.

Foley, J.A., N. Ramankutty, K.A. Brauman, E.S. Cassidy, J.S. Gerber, M. Johnston, N.D. Mueller, C. Connell, et al. 2011. Solutions for a cultivated planet. Nature 478: 337-342. https://doi.org/10. 1038/nature10452.

Fowler, D., M. Coyle, U. Skiba, M.A. Sutton, J.N. Cape, S. Reis, L.J. Sheppard, A. Jenkins, et al. 2013. The global nitrogen cycle in the twenty-first century. Philosophical Transactions of the Royal Society of London. Series B, Biological sciences 368: 20130164. https://doi.org/10.1098/rstb.2013.0164.

Kanter, D.R., O. Chodos, O. Nordland, M. Rutigliano, and W. Winiwarter. 2020. Gaps and opportunities in nitrogen pollution policies around the world. Nature Sustainability. https://doi.org/ 10.1038/s41893-020-0577-7.

Khurana, H.S., S.B. Phillips, M.M. Bijay-Singh, A. Alley, A.S. Sidhu, Yadvinder-Singh, and S.B. Peng. 2008. Agronomic and economic evaluation of site-specific nutrient management for irrigated wheat in northwest India. Nutrient Cycling in Agroecosystems 82: 15-31.

Ladha, J.K., and P.M. Reddy. 1995. Extension of nitrogen fixation to rice? Necessity and possibilities. GeoJournal 35: 363-372. https://doi.org/10.1007/BF00989144.

Ladha, J.K., A. Tirol-Padre, C.K. Reddy, K.G. Cassman, S. Verma, D.S. Powlson, C. van Kessel, D. de Richter, et al. 2016. Global nitrogen budgets in cereals: A 50-year assessment for maize, rice, and wheat production systems. Scientific Reports 6: 19355. https://doi.org/10.1038/srep19355.

Lassaletta, L., G. Billen, B. Grizetti, J. Anglade, and J. Garnier. 2014. 50 year trends in nitrogen use efficiency of world cropping systems: The relationship between yield and nitrogen input to cropland. Environmental Research Letters 9: 105011.

Lowenberg-DeBoer, J., and B. Erickson. 2019. Setting the record straight on precision agriculture adoption. Agronomy Journal 111: 1552-1569. https://doi.org/10.2134/agronj2018.12.0779.

Ma, L., Z. Bai, W. Ma, M. Guo, R. Jiang, J. Liu, O. Oenema, G.L. Velthof, et al. 2019. Exploring future food provision scenarios for China. Environmental Science and Technology 53: 1385-1393. https://doi.org/10.1021/acs.est.8b04375.

McLellan, E., D. Robertson, K. Schilling, M. Tomer, J. Kostel, D. Smith, and K. King. 2015. Reducing nitrogen export from the Corn Belt to the Gulf of Mexico: Agricultural strategies for remediating hypoxia. JAWRA Journal of the American Water Resources Association 51: 263-289. https://doi.org/10.1111/ jawr.12246.

McLellan, E.L., K.G. Cassman, A.J. Eagle, P.B. Woodbury, S. Sela, C. Tonitto, R.D. Marjerison, and H.M. van Es. 2018. The nitrogen balancing act: Tracking the environmental performance of food production. BioScience 68: 194-203. https://doi.org/10. 1093/biosci/bix 164 .

Pampolino, M.F., I.J. Manguiat, S. Ramanathan, H.C. Gines, P.S. Tan, T.T.N. Chi, R. Rajendran, and R.J. Buresh. 2007. Environmental impact and economic benefits of site-specific nutrient management (SSNM) in irrigated rice systems. Agricultural Systems 93: 1-24.

Pampolino, M.F., C. Witt, J.M. Pasuquin, A. Johnston, and M.J. Fisher. 2012. Development approach and evaluation of the Nutrient Expert software for nutrient management in cereal crops. Computers and Electronics in Agriculture 88: 103-110. https://doi.org/10.1016/j.compag.2012.07.007.

Pasuquin, J.M., M.F. Pampolino, C. Witt, A. Dobermann, T. Oberthur, M.J. Fisher, and K. Inubushi. 2014. Closing yield gaps in maize production in Southeast Asia through site-specific nutrient management. Field Crops Research 156: 219-230.

Quemada, M., L. Lassaletta, L.S. Jensen, O. Godinot, F. Brentrup, C. Buckley, S. Foray, S.K. Hvid, et al. 2020. Exploring nitrogen indicators of farm performance among farm types across several European case studies. Agricultural Systems 177: 102689. https://doi.org/10.1016/j.agsy.2019.102689.

Rogers, C., and G.E.D. Oldroyd. 2014. Synthetic biology approaches to engineering the nitrogen symbiosis in cereals. Journal of Experimental Botany 65: 1939-1946. https://doi.org/10.1093/ jxb/eru098.

Rurinda, J., S. Zingore, J.M. Jibrin, T. Balemi, K. Masuki, J.A. Andersson, M.F. Pampolino, I. Mohammed, et al. 2020. Sciencebased decision support for formulating crop fertilizer recommendations in sub-Saharan Africa. Agricultural Systems 180: 102790.

Saikai, Y., V. Patel, and P.D. Mitchell. 2020. Machine learning for optimizing complex site-specific management. Computers and Electronics in Agriculture 174: 105381. https://doi.org/10.1016/ j.compag.2020.105381.

Saito, K., S. Diack, I. Dieng, and M.K. N'Diaye. 2015. On-farm testing of a nutrient management decision-support tool for rice in the Senegal River valley. Computers and Electronics in Agriculture 116: 36-44. https://doi.org/10.1016/j.compag.2015.06. 008.

Salvagiotti, F., K.G. Cassman, J.E. Specht, D.T. Walters, A. Weiss, and A. Dobermann. 2008. Nitrogen uptake, fixation and response to fertilizer N in soybeans: A review. Field Crops Research 108: $1-13$. 
Senthilkumar, K., J. Rodenburg, I. Dieng, E. Vandamme, F.S. Sillo, J.-M. Johnson, A. Rajaona, J.A. Ramarolahy, et al. 2020. Quantifying rice yield gaps and their causes in Eastern and Southern Africa. Journal of Agronomy and Crop Science 206: 478-490. https://doi.org/10.1111/jac.12417.

Sharma, S., P. Panneerselvam, R. Castillo, S. Manohar, R. Raj, V. Ravi, and R.J. Buresh. 2019. Web-based tool for calculating field-specific nutrient management for rice in India. Nutrient Cycling in Agroecosystems 113: 21-33. https://doi.org/10.1007/ s10705-018-9959-x.

Smith, M.J. 2020. Getting value from artificial intelligence in agriculture. Animal Production Science 60: 46. https://doi.org/ 10.1071/AN18522.

Springmann, M., M. Clark, D. Mason-D'Croz, K. Wiebe, B.L. Bodirsky, L. Lassaletta, W. de Vries, S.J. Vermeulen, et al. 2018. Options for keeping the food system within environmental limits. Nature 562: 519-525. https://doi.org/10.1038/s41586018-0594-0.

Steffen, W., K. Richardson, J. Rockström, S.E. Cornell, I. Fetzer, E.M. Bennett, R. Biggs, S.R. Carpenter, et al. 2015. Sustainability. Planetary boundaries: Guiding human development on a changing planet. Science 347: 1259855. https://doi.org/10.1126/ science. 1259855.

Subbarao, G.V., J. Arango, K. Masahiro, A.M. Hooper, T. Yoshihashi, Y. Ando, K. Nakahara, S. Deshpande, et al. 2017. Genetic mitigation strategies to tackle agricultural GHG emissions: The case for biological nitrification inhibition technology. Plant Science 262: 165-168.

ten Berge, H.F.M., R. Hijbeek, M.P. van Loon, J. Rurinda, K. Tesfaye, S. Zingore, P. Craufurd, J. van Heerwaarden, et al. 2019. Maize crop nutrient input requirements for food security in sub-Saharan. Africa 23: 9-21.

Uwizeye, A., I.J.M. de Boer, C.I. Opio, R.P.O. Schulte, A. Falcucci, G. Tempio, F. Teillard, F. Casu, et al. 2020. Nitrogen emissions along global livestock supply chains. Nature Food. https://doi. org/10.1038/s43016-020-0113-y.

van Grinsven, H.J.M., L. Bouwman, K.G. Cassman, H.M. van Es, M.L. McCrackin, and A.H.W. Beusen. 2015. Losses of ammonia and nitrate from agriculture and their effect on nitrogen recovery in the European Union and the United States between 1900 and 2050. Journal of Environmental Quality 44: 356-367. https://doi. org/10.2134/jeq2014.03.0102.

van Ittersum, M.K., L.G.J. van Bussel, J. Wolf, P. Grassini, J. van Wart, N. Guilpart, L. Claessens, H. de Groot, et al. 2016. Can sub-Saharan Africa feed itself? Proceedings of the National Academy of Sciences 113: 14964-14969. https://doi.org/10.1073/ pnas. 1610359113.

van Lammerts Bueren, E.T., and P.C. Struik. 2017. Diverse concepts of breeding for nitrogen use efficiency. A review. Agronomy for
Sustainable Development. https://doi.org/10.1007/s13593-0170457-3.

van Zanten, H.H.E., M.K. van Ittersum, and I.J.M. de Boer. 2019. The role of farm animals in a circular food system 21: 18-22. https:// doi.org/10.1016/j.gfs.2019.06.003.

Vollset, S.E., E. Goren, C.-W. Yuan, J. Cao, A.E. Smith, T. Hsiao, C. Bisignano, G.S. Azhar, et al. 2020. Fertility, mortality, migration, and population scenarios for 195 countries and territories from 2017 to 2100: A forecasting analysis for the Global Burden of Disease Study. The Lancet. https://doi.org/10.1016/S01406736(20)30677-2.

Wang, Y., C. Li, Y. Li, L. Zhu, S. Liu, L. Yan, G. Feng, and Q. Gao. 2020. Agronomic and environmental benefits of nutrient expert on maize and rice in Northeast China. Environmental Science and Pollution Research. https://doi.org/10.1007/s11356-02009153-w.

Willett, W., J. Rockström, B. Loken, M. Springmann, T. Lang, S. Vermeulen, T. Garnett, D. Tilman, et al. 2019. Food in the Anthropocene: The EAT-Lancet Commission on healthy diets from sustainable food systems. The Lancet 393: 447-492. https:// doi.org/10.1016/S0140-6736(18)31788-4.

Zhang, X., E.A. Davidson, D.L. Mauzerall, T.D. Searchinger, P. Dumas, and Y. Shen. 2015. Managing nitrogen for sustainable development. Nature 528: 51-59. https://doi.org/10.1038/ nature 15743.

Zhang, X., E.A. Davidson, T. Zou, L. Lassaletta, Z. Quan, T. Li, and W. Zhang. 2020. Quantifying nutrient budgets for sustainable nutrient management. Global Biogeochemical Cycles. https:// doi.org/10.1029/2018GB006060.

Zossou, E., K. Saito, A. Assouma-Imorou, K. Ahouanton, and B.D. Tarfa. 2020. Participatory diagnostic for scaling a decision support tool for rice crop management in northern Nigeria. Development in Practice. https://doi.org/10.1080/09614524. 2020.1770699 .

Publisher's Note Springer Nature remains neutral with regard to jurisdictional claims in published maps and institutional affiliations.

\section{Kenneth G. Cassman ( $\square)$}

Address: University of Nebraska, 202 Keim Hall, Lincoln, NE 68583, USA.

e-mail: kcassman1@unl.edu

\section{Achim Dobermann}

Address: International Fertilizer Association, 49 Avenue d'Iena, 75116 Paris, France.

e-mail: adobermann@fertilizer.org 